\title{
MENINGKATKAN NIAT BERKUNJUNG PADA GENERASI MUDA MELALUI CITRA DESTINASI DAN DAYA TARIK KAMPUNG WISATA
}

\author{
Mega Mirasaputri Cahyanti \\ Widiya Dewi Anjaningrum \\ Dosen STIE AsiA Malang
}

\begin{abstract}
Abstrak
Penelitian ini bertujuan untuk mengetahui pengaruh variabel citra destinasi dan daya tarik wisatawan terhadap niat wisatawan pada generasi muda untuk mengunjungi jenis destinasi yaitu Kampung Wisata Tridi. Penelitian ini merupakan penelitian kausal, dimana data primer kuantitatif diolah melalui instrumen berupa kuesioner yang diambil langsung dari para wisatawan di destinasi wisata dan termasuk pada golongan generasi muda. Untuk dapat memenuhi kriteria dari sampel yang dibutuhkan dalam penelitian ini, tekhnik sampling yang digunakan adalah purposive sampling dengan pertimbangan bahwa sampel yang dipilih memiliki usia yang termasuk pada rentang 17-33 tahun, dan bersedia mengisi kuesioner. Dari terget yang telah ditentukan, terkumpul sampel sebanyak 50 responden. Adapun hasil olah data dan analisis regresi berganda dengan menggunakan SPSS 23 menunjukan bahwa kedua variabel bebas dalam penelitian ini, yaitu citra destinasi dan daya tarik wisata memiliki pengaruh yang signifikan untuk menciptakan niat generasi muda mengunjungi kampung wisata Tridi. Namun, apabila membandingkan nilai koefisien regresi dan nilai signifikansi antara variabel citra destinasi dan daya tarik wisata, didapatkan variabel daya tarik wisata memiliki pengaruh signifikan yang lebih kuat dibandingkan dengan citra destinasi.
\end{abstract}

Kata Kunci : niat berkunjung, citra destinasi, daya tarik wisata, generasi muda, kampung wisata.

\begin{abstract}
This study aims to determine the effects of destination image and tourism attractiveness variables on intention of young generation to visit a rural tourism destination such as "Kampung Wisata Tridi". This research is a kind of causal research, where the primary quantitative data through questionnaire was taken directly from a tourists in tourism destination and also them who included as young generation. To fulfill the criteria of sample that needed on this research, the sampling technique was used is purposive sampling, by the consideration that sampling choosen is vary between 17-33 years old, and willing to fill the questionnaire. Based on the target that researcher have, a predetermine number of samples that taken was 50 respondents. Based on the result taken by data processing using SPSS 23, shows that the variable which effect significantly the intention to visit a tourism destination are destination image and tourism attractiveness. In other hand, variable which effect most significantly was tourism attractiveness compare with destination image.

Key Words: intention to visit tourism destination, destination image, tourism attractiveness, young generation, rural tourism.
\end{abstract}

\section{PENDAHULUAN}

Terdapat fenomena yang terjadi pada masyarakat Indonesia dimana para generasi muda saat ini memiliki pandangan baru dalam memenuhi gaya hidup, yaitu melakukan traveling. Menurut data Badan Pusat Statistik (BPS) menuliskan terdapat 1,1 juta orang melakukan traveling keluar negeri menggunakan transportasi pesawat terbang. Jumlah tersebut meningkat dari bulan Febuari 2013 sebanyak 16,29 persen atau sebesar 950.300 orang, yang didominasi oleh generasi muda. Berdasarkan data diatas dapat disimpulkan bahawa melakukan liburan keluar negri menjadi hal yang familiar dilakukan generasi muda untuk menghabiskan waktu libur yang dimiliki.

Tingkat kunjungan wisatawan muda keluar negri merupakan issue utama bagi destinasi dalam negri. Fenomena penurunan wisatawan muda domestik yang terus terjadi apabila destinasi wisata dalam negri tidak dapat menyediakan pilihan berwisata yang menarik, akan memberikan dampak negatif terhadap perekonomian Indonesia.
Niat dan kebutuhan wisatawan muda terhadap pemilihan destinasi wisata akan berubah setiap waktu menyesuaikan tren pariwisata pada masa itu. Dalam penelitian yang telah di lakukan oleh TripAdvisior pada tahun 2014, sebesar 94\% mayoritas wisatawan asing di dunia menjatuhkan pilihan liburannya untuk tempat-tempat rekreasi yang memberikan penawaran wisata menarik, murah atau khusus. Karena pada umumnya, jenis wisata diatas dapat memberikan sebuah pengalaman baru yang dapat memberikan memori yang berkesan.

Melihat lebih jauh tentang generasi muda, karakteristik generasi muda yang tergolong pada generasi $\mathrm{Y}$ adalah mereka yang memiliki karakteristik sebagai berikut; (a) berusia dibawah 34 tahun; (b) lahir pada periode tahun 1980 - 1990; (c) generasi yang akrab dengan internet atau media sosial; (d) tidak takut perubahan; (e) namun terkadang suka tidak sabar melalui proses perubahan tersebut; (f) dan seringkali memiliki ideide brilian. Dengan demikian, masih terdapat 
pertanyaan yang belum terjawab mengenai, hal apa saja yang dapat menarik niat berkunjung pada generasi muda dengan karakteristik seperti diatas.

Di Kota Malang, terdapat jenis destinasi baru yang khusus yang ditawarkan oleh pemerintah kota melalui Dinas Budaya dan Pariwisata. Daya tarik wisata tersebut bernama "Kampung Wisata". Kampung wisata sendiri termasuk dalam jenis rural tourism. Dimana konsep dasar dari pariwisata ini adalah memberdayakan potensi daerah yang terpencil guna meningkatkan pendapatan masyarakat sekitar.

Kampung Wisata pertama yang terbentuk dan sampai saat ini masih diminati oleh wisatawan adalah Kampung Wisata Warna Warni yang terletak di Kelurahan Jodipan, Kecamatan Blimbing. Disekitar daerah itu, terdapat pula kampung wisata yang dibuat lagi dan baru mulai dipromosikan kepada para wisatawan yang diberi nama Kampung Wisata Tridi. Kampung Wisata Tridi berlokasi tidak jauh dari Kampung Warna Warni, namun jumlah wisatawan yang berkunjung masih belum sebanyak Kampung Warna Warni. Dengan demikian, peneliti tertarik untuk melakukan penelitian pada Kampung Wisata Tridi yang terletak pada Kelurahan Ksatrian, Kecamatan Blimbing.

Pariwisata kampung adalah pariwisata yang dibangun dengan tema kampung tematik. Tema pariwisata kampung ini tergantung dari jenis kampung yang menjadi daya tarik utama dari pariwisata, misalnya kampung dengan daya tarik pertanian, akan di bangun pariwisata agrowisata dan kampung dengan daya tarik seni budayanya, maka akan cocok untuk di bangun menjadi pariwisata pedesaan dengan tema seni dan budaya.

Kesungguhan pemerintah dalam membangun kampung wisata sangat tercermin pada diselenggarakannya lomba konsep dan gagasan pembuatan kampung wisata dan anggaran dana yang disediakan untuk merealisasikan konsep dan gagasan yang terpilih sebagai pemenang. Namun pada kenyataanya, kampung wisata yang sudah terealisasi pada dua kecamatan di Kota Malang masih kurang pengunjung. Apabila pemerintah serius dalam membangun kampung wisata ini, maka konsep destinasi baru ini akan menjadi salah satu destinasi unggulan di Kota Malang dan masyarakat di masing-masing kecamatan juga akan terangkat perekonomiannya.

Menurut Page \& Connell, 2006: 427, rural tourism sering digambarkan sebagai bentuk pariwisata yang terjadi di pedesaan tetapi ini adalah ambigu pada poin beberapa poin selanjutnya mengenai variasi luas jenis pedesaan dan kegiatan. Oleh karena itu, konsep rural tourism pada penelitian ini menyimpulkan yaitu sebuah tempat wisata terpelosok yang menyediakan daya tarik pariwisata. Bramwell (2006) selajutnya menjelaskan bahwa, ciri khusus dari kampung yang berbentuk pola pariwisata, menciptakan bentuk spesifik dari kampung wisata. Beragam jenis kampung wisata akan tergantung oleh perbedaan dari kondisi produk pariwisata di suatu wilayah perkampungan.

Selain daripada daya tarik yang dimiliki oleh kampung wisata pada Kampung Tridi, menurut Handawan (2015), citra destinasi merupakan salah satu hal penting yang perlu diperhatikan untuk memunculkan niat berkunjung pada tujuan wisata. Citra destinasi sendiri menurut Echner \& Ritchie dalam Jorgensen (2004:13) sebagai "kesan tempat" atau "persepsi area" yang dimiliki oleh masing-masing individu.

Berdasarkan uraian diatas peneliti mengambil penelitian yang berjudul

"Meningkatkan Niat Berkunjung Pada Generasi Muda Melalui Citra Destinasi Dan Daya Tarik Kampung Wisata".

\section{RUMUSAN MASALAH}

a. Apakah citra destinasi kampung wisata mampu mempengaruhi wisatawan generasi muda untuk memiliki niat berkunjung.

b. Apakah daya tarik wisata yang ditawarkan oleh masing-masing kampung wisata mampu mempengaruhi wisatawan generasi muda untuk memiliki niat berkunjung.

\section{TUJUAN PENELITIAN}

Tujuan yang akan dicapai dari penelitian ini adalah untuk mengetahui pengaruh citra destinasi dan daya tarik yang dimiliki oleh kampung wisata Tridi terhadap niat berkunjung pada wisatawan generasi muda.

\section{TINJAUAN PUSTAKA}

\section{a. Citra Destinasi}

Citra destinasi secara umum didefinisikan dalam literatur sebagai total keyakinan, ide dan kesan seseorang dari terhadap tujuan wisata (Crompton, 1979; Kotler, Haider, \& Rein, 1993). Selain itu, peneliti lain berpendapat bahwa citra tidak hanya ciri-ciri dari objek itu sendiri atau kualitas yang dimilikinya melainkan kesan keseluruhan yang dibuat secara kesatuan pada pemikiran masing-masing individu (Echtner \& Ritchie, 1991). Berdasarkan pendapat tersebut, peneliti merasa terdapat pengertian yang lebih rumit untuk menjelaskan tentang sebuah citra. Dimana didalam sebuah citra, terdapat dua konsep yang tidak dapat dipisahkan, yaitu kognitif dan afektif yang terlibat dalam pembentukan citra secara keseluruhan. Membedakan komponen kognitif dan afektif adalah alat metodologis dan konseptual untuk memfasilitasi pengukuran yang cermat terhadap variabel citra.

Komponen kognitif dari citra mengacu pada keyakinan dan pengetahuan seseorang tentang tujuan wisata dan segala macam atribut yang 
dimilikinya, yang bersama-sama membantu membentuk gambaran tempat destinasi wisata.

Di sisi lain, komponen afektif dari citra menunjukkan perasaan seseorang terhadap dan tanggapan emosional yang diperoleh dari tujuan wisata. Sehingga dapat disimpulkan bahwa kognitif adalah kegiatan dalam memperoleh, mengolah, mengorganisasi, dan menggunakan pengetahuan. Sedangkan afektif berkaitan dengan perasaan atau emosi.

Dengan demikian, keseluruhan citra destinasi yang dimiliki oleh wisatawan generasi muda dapat mempengaruhi tidak hanya pemilihan tempat wisata, tetapi juga perilaku wisatawan yang terkait (Chen \& Tsai, 2007; Qu, Kim, \& Im, 2011; Wang \& Hsu, 2010). Salah satu variabel yang paling sering digunakan untuk menangkap niat perilaku turis adalah keseluruhan citra destinasi baik secara kognitif maupun afektif.

Beberapa penelitian mengungkap bahawa citra destinasi berpengaruh terhadap niat wisatawan untuk mengunjungi sebuah tempat wisata dan juga bersedia untuk merekomendasikan tujuan wisata tersebut kepada orang lain (Chi \& Qu, 2008; Choi, Tkachenko, \& Sil, 2011; Ramkissoon, Uysal, \& Brown, 2011). Namun penelitian yang paling penting adalah penelitian yang dilakukan oleh Wang dan Hsu (2010) dan Qu dkk. (2011), menunjukan bahwa kedua komponen kognitif dan afektif mempengaruhi gambaran keseluruhan citra destinasi yang secara langsung mampu mempengaruhi niat perilaku mereka. Berdasarkan penjelasan diatas, hipotesis pertama yang akan diuji adalah :

H1 : Citra destinasi secara keseluruhan berpengaruh signifikan terhadap niat berkunjung.

\section{b. Daya Tarik Wisata}

Daya tarik wisata merupakan kata lain dari obyek wisata namun sesuai peraturan pemerintah Indonesia Tahun 2009, kata obyek wisata sudah tidak relevan lagi untuk menyebutkan suatu daerah tujuan wisatawan maka digunakanlah kata "Daya Tarik Wisata".

Berdasarkan penelitian terdahulu, daya tarik wisata dapat diartikan sebagai berikut, diantaranya ada yang berpendapat bahwa daya tarik wisata adalah semua hal yang dapat menciptakan perasaan tertarik dan merasa memiliki nilai positif untuk didatangi dan dilihat (Pendit, 1994). Daya tarik wisata merupakan produk wisata dalam suatu kesatuan tidak hanya keindahan alam dari destinasi tersebut, tetapi meliputi atribut lainnya seperti daya tarik, fasilitas dalam saat berwisata, dan juga akses menuju tempat wisata tersebut (Ali, 2012).

Berdasarkan Basiya dan Rozak (2012), terdapat motivasi utama bagi para pengunjung untuk melakukan kunjungan wisata yaitu daya tarik destinasi. Destinasi wisata dapat dikelompokan menjadi empat daya tarik, diantaranya adalah : 1 .
Daya tarik wisata alam (natural attraction) yang meliputi pemandangan alam daratan, pemandangan alam lautan, pantai, iklim atau cuaca. 2. Daya tarik wisata berupa arsitektur bangunan (building attraction) yang meliputi bangunan dan arsitektur bersejarah, bangunan dan arsitektur modern, arkeologi. 3. Daya tarik wisata yang dikelola khusus (managed visitor attractions), yang meliputi tempat peninggalan kawasan industri. 4. Daya tarik wisata budaya (cultural attraction) yang meliputi teater, musium, tempat bersejaah, adat-istiadat, tempat-tempat religius, peristiwa-peristiwa khusus seperti festival dan drama bersejarah (pageants), dan heritage seperti warisan peninggalan budaya. 5. Daya tarik wisata sosial seperti gaya hidup penduduk di tempat tujuan wisata. Elemen-elemen daya tarik tempat tujuan wisata merupakan pilihan pengunjung dan yang mendorong bagi pengunjung untuk melakukan kunjungan wisata.

Dalam penelitian ini, daya tarik dari kampung wisata termasuk dalam kelompok wisata yang dikelola khusus. Pengelola khusus yang dimaksud adalah para masyarakat lokal yang diberdayakan untuk menjalankan operasional dari wisata tersebut. Sehingga, semakin kreatif daya tarik yang dibuat oleh masyarakat lokal dapat meningkatkan motivasi utama untuk melakukan kunjungan kekampung wisata tersebut. Salah satu daya tarik yang terdapat pada kampung Tridi yaitu gambar tiga dimensi (gambar 1) didinding, selain itu tiket masuk yang dibayarkan oleh wisatawan sudah termasuk souvenir yang dibuat langsung oleh ibu-ibu PKK sebagai masyarakat lokal.

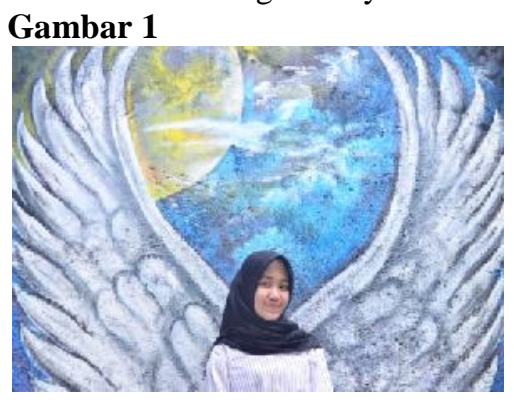

\section{a. Kampung Wisata Tridi Kota Malang}

Menurut para peneliti, tidak ada definisi yang baku mengenai rural tourism yang tercatat dalam literatur terdahulu. Berdasarkan Ratz dan Puczko (1998) rural tourism adalah sebuah fenomena baru yang muncul pada tahun 1990-an karena ada ketertarikan para wisatawan untuk mengunjungi tempat wisata didaerah pinggiran kota. Berdasarkan literatur yang ada, kampung wisata sendiri dapat tergolong dalam jenis rural tourism, atau pariwisata yang berlokasi diluar kota besar.

Menurut Wiendu (1993), definisi dari kampung wisata adalah perpaduan antara atraksi, akomodasi dan fasilitas pendukung yang dapat diakses pada susunan kehidupan masyarakat lokal dengan tradisi dan tata cara yang berlaku. 
Kampung wisata adalah suatu wilayah pelosok atau yang biasa disebut perkampungan yang memiliki daya tarik tertentu seperti sosial budaya, pertanian, adat istiadat, sturktur ruang kampung, maupun wisata alam yang disajikan. Selain itu, kampung wisata biasanya memiliki usaha kecil dan rumahan, kontak masyarakat lokal dan praktek - praktek tradisional (Page \& Connell, 2006: 428).

Dalam penelitian ini, definisi dari kampung wisata merujuk pada pendapat menurut Wiendu (1993) dan (Page \& Connell, 2006: 428).

Pada Kampung wisata Tridi, pemerintah bekerjasama dengan masyarakat lokal membuat konsep yaitu membuat gambar tiga dimensi hampir diseluruh dinding rumah. Semua gambar tiga dimensi tersebut dibuat oleh para pelukis yang berasal dari masyarakat lokal maupun bantuan dari mahasiswa/i yang terlibat dalam project pengembangan Kampung Wisata di Kota Malang. Selain gambar tiga dimensi, daya tarik lain yang diberikan kepada wisatawan adalah pemberian souvenir yang berupa gantungan kunci yang khusus dibuat oleh masyarakat sebagai pengganti tiket masuk yang telah dibayarkan.

Tujuan utama dari pemerintah Kota Malang dalam pembuatan kampung wisata ini adalah untuk memberdayakan masyarakat lokal sebagai pengelola kampung wisata. Dengan harapan dapat membuat pola pikir warga untuk turut berubah dengan usahanya sendiri untuk meneruskan dan mengembangkan kampung wisata yang berada di daerahnya masing-masing, sehingga selanjutnya masyarakat lokal tidak hanya berharap dari bantuan pemerintah Kota Malang saja. Walaupun pembuatan awal dari kampung wisata mayoritas merupakan pemberian bantuan dari pemerintah, namun masyarakat lokal harus belajar agar bisa mandiri.

\section{b. Niat Berkunjung}

Kata niat dapat didefinisikan sebagai ketertarikan (interest) yang dirasakan oleh seorang individu terhadap suatu hal. Dalam bidang pemasaran pariwisata, dapat dikerucutkan lagi definisi niat adalah ketertarikan yang dapat dirasakan oleh wisatawan terhadap suatu tempat wisata yang memiliki daya tarik tertentu (Ismail, 2004:92).

Wisatawan dapat tertarik pada sebuah destinasi wisata karena berbagai sebab, diantaranya: 1. Karena fitur dari produk/jasa, dalam hal ini wisatawan tertarik pada sebuah destinasi wisata karena penampakannya yang menarik. 2 . Karena manfaat produk/jasa, dalam hal ini konsumen tertarik kepada suatu destinasi wisata karena manfaat yang akan didapatkan oleh wisatawan.

Motivasi yang membangkitkan niat berkunjung pada suatu destinasi antara generasi muda dengan generasi tua memiliki suatu perbedaan yang mendasar. Menurut Dewi (2013), bangsa Indonesia yang memiliki budaya kolektivis, menerapkan budaya malu-malu secara turun temurun. Namun, dewasa ini budaya malu terlihat pudar ditinjau dari pergeseran sikap dan perilaku yang ditampilkan oleh masyarakat. Perilaku-perilaku yang dulunya dapat menimbulkan rasa malu sehingga sering dilakukan secara sembunyi-sembunyi, kini menjadi perilaku yang dilakukan secara terang-terangan. Dari hasil penelitian yang dilakukan oleh Diara (2013), dapat disimpulkan bahwa terdapat perbedaan yang signifikan pada budaya malu antara generasi tua dan generasi muda. Perbedaan diatas diyakini oleh peneliti dapat mempengaruhi niat berkunjung wisatawan yang tergolong pada perbedaan generasi dalam bersikap untuk mengunjungi sebuah destinasi wisata. Sebagai contoh, generasi muda akan lebih mempertimbangkan tempat wisata yang memiliki tampilan bagus dan menarik untuk dijadikan tempat ber-selfie, atau berfoto diri sendiri (swafoto). Perilaku tersebut sering dilakukan oleh generasi muda bahkan ditempat ramai sekalipun dan tanpa memikirkan orang sekitar yang berada disana apakah merasa terganggu atau tidak dengan tindakan yang mereka lakukan. Dan tentunya, perilaku tersebut jarang sekali dilakukan oleh generasi tua dalam melakukan kegiatan berwisata mereka.

Dengan demikian, peneliti akan lebih memfokuskan penelitian mengenai niat berkunjung ke kampung wisata yang tergolong dari jenis wisata baru di Kota Malang, dengan menggunakan persepsi dari generasi muda

\section{Kerangka Konseptual Dan Hipotesis}

Berikut ini adalah gambar bagan kerangka konseptual penelitian ini, dimana diduga variabel bebas mempengaruhi variabel terikat.

\section{Gambar 2. Kerangka Penelitian}

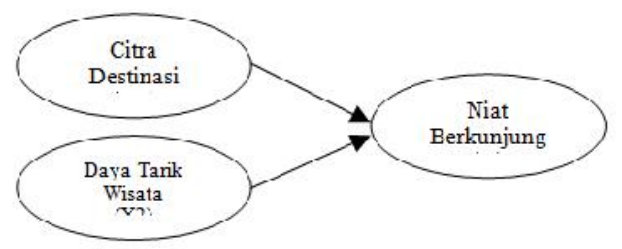

Adapun hipotesis-hipotesis yang diambil dalam penelitian ini antara lain:

H1: Terdapat pengaruh yang signifikan antara citra destinasi terhadap niat berkunjung pada generasi muda.

H2: Terdapat pengaruh yang signifikan antara daya tarik wisata terhadap niat berkunjung pada generasi muda.

\section{METODOLOGI PENELITIAN}

Penelitian ini termasuk ke dalam penelitian kuantitatif, dan dari tujuannya penelitian ini tergolong pada penelitian kausal karena peneliti ingin mengetahui hubungan sebab-akibat antara variabel. Populasi dari penelitian ini adalah seluruh wisatawa dari Kampung Wisata Tridi yang tergolong pada generasi muda. Adapun yang dimaksud dengan generasi muda adalah mereka yang berusia 17-33 tahun. Prosedur pengambilan sampel yang digunakan dalam penelitian ini adalah non-probability sampling, dengan tekhnik purposive sampling, yaitu peneliti memilih sampel berdasarkan ketersediaan dan kesediaan dari 
subjek, selain itu mereka harus termasuk dalam rentang usia yang telah ditentukan sebagai generasi muda, serta tentu saja mereka yang bersedia untuk mengisi kuesioner (Gravetter \& Forzano, 2009). Selain itu mereka haruslah wisatawan yang sedang berkunjung di Kampung Wisata Tridi pada saat peneliti menyebar kuesioner, yaitu dalam jangka waktu 10 hari, dengan banyakanya target sampel adalah 5 orang per hari. Sehingga jumlah target sampel yang dapat dikumpulkan adalah 50 wisatawan.

Definisi Operasional Variabel dan Metode Pengukuran

Terdapat tiga variabel yang diteliti dalam penelitian ini, yaitu dua variabel bebas dan satu variabel terikat.

\section{Tabel 1. Definisi Operasional Variabel} Penelitian.

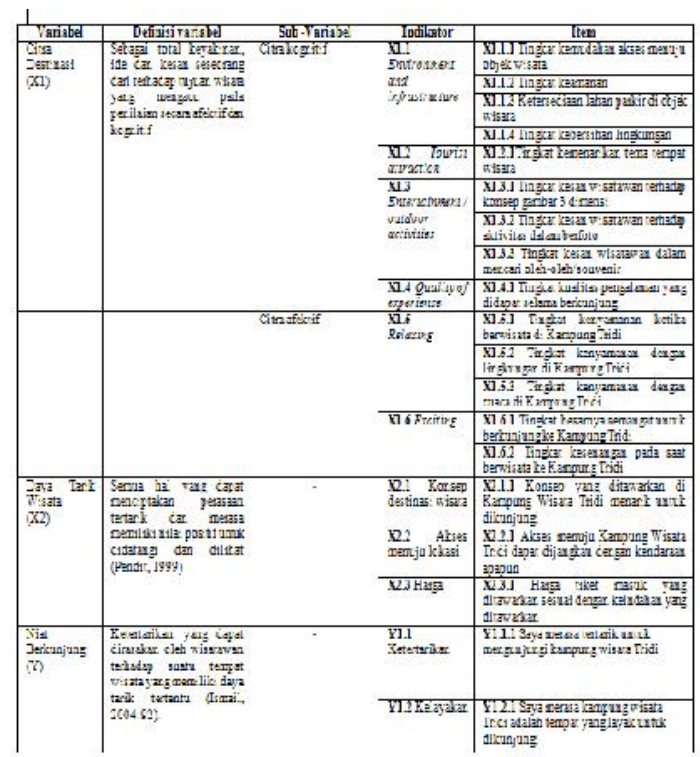

HASIL DAN PEMBAHASAN

a. Pemenuhan Asumsi

Sebanyak 50 data hasil kuesioner dari sampel yang dipilih dalam penelitian ini telah memenuhi uji validitas dan reliabilitas dengan hasil Sig. (2-tailed) dari tiga variabel (baik variabel bebas maupun terikat) terhadap variabel total sebesar 0,000 lebih kecil dari 0,1 (taraf signifikansi 10\%). Sedangkan nilai Cronbach's Alpha sebesar 0,888 . Demikian juga pemenuhan uji asumsi klasik yang meliputi normalitas, multikolinearitas dan heteroskedasitas. Nilai Asymp. Sig. (2-tailed) pada tabel One-Sample Kolmogorov-Smirnov Test menunjukan nilai $0,200>0,05$, sehingga dapat disimpulkan bahwa semua data pada setiap variabel telah terdistribusi secara normal. Nilai VIF semua variabel bebas dalam tabel Coefficients dalam output SPSS menunjukan angka kurang dari 10 yang berarti tidak terjadi multikolinearitas. Scatterplot dalam output SPSS juga tidak menunjukkan pola tertentu sehingga dapat disimpulkan tidak terjadi heteroskedastisitas

\section{b. Koefisien determinasi}

Berdasarkan tabel 2 dapat diketahi bahwa nila $R$ Square yang berfungsi untuk melihat seberapa besar kontribusi seluruh variabel bebas terhadap variabel terikat adalah sebesar 0,752. Artinya $75,2 \%$ niat berkunjung wisatawan pada generasi muda yang mengunjungi kampung wisata Tridi dijelaskan oleh daya tarik wisata dan citra destinasi.

Tabel 2. Koefisien Determinasi

Yodel Summarty
\begin{tabular}{|l|l|l|l|l|}
\hline Model & $R$ & R Square & $\begin{array}{l}\text { AdjustedR } \\
\text { Square }\end{array}$ & $\begin{array}{l}\text { Std. Error of the } \\
\text { Estimate }\end{array}$ \\
\hline 1 &, $867^{3}$ & 752 &, 742 & 1,035 \\
\hline
\end{tabular}
a. Predictor: (Constant),Dava Tarik Wisata: Citra Destinasi
b. Dependent Variable: Niat Berkunjung

Sedangkan sisanya sebesar $24,8 \%$ dijelaskan oleh variabel-variabel lain yang tidak dipertimbangkan dalam penelitian ini.

\section{c. Uji F dan Uji t}

Berdasarkan tabel 3, ditunjukan bahwa nilai Fhitung sebesar 71,421 lebih besar dari Ftabel sebesar 3,195, dan nilai signifikansi nya sebesar 0,000 lebih kecil dari 0,1 (taraf signifikansi 10\%), artinya bahwa model regresi yang akan dibentuk telah memenuhi goodness of fit model atau model regresi yang dibentuk dapat memprediksi niat berkunjung wisatawan generasi muda di Kampung Wisata.

Tabel 3. Tabel Anova

\begin{tabular}{|c|c|c|c|c|c|}
\hline \multicolumn{6}{|c|}{ AYONA ${ }^{1}$} \\
\hline Model & Sumof Squares & df & Mean Square & $\mathrm{F}$ & Sig. \\
\hline 1 Regiession & 152,953 & 2 & 76,476 & 71,421 & $000^{k}$ \\
\hline Residtal & 50,327 & 47 & 1,071 & & \\
\hline Tota] & 203,280 & 49 & & & \\
\hline
\end{tabular}

Sedangkan untuk uji t, dapat dilihat pada tabel 4 dimana nilai $\mathrm{t}$ hitung dari variabel citra destinasi $(3,232)$ dan daya tarik wisata $(5,422)$ berada pada daerah yang diarsir (gambar 3), yaitu lebih besar dari 2,01. Dengan tingkat signifikansi $0,002<0,05$ (tingkat signifikansi) untuk variabel citra destinasi dan tingkat signifikansi $0,000<0,05$ (tingkat signifikansi) untuk variabel daya tarik wisata. Sehingga dapat disimpulkan bahwa H1 diterima untuk variabel citra destinasi, dan $\mathrm{H} 2$ diterima untuk daya tarik wisata. Atau dengan kata lain, citra destinasi berpengaruh signifikan terhadap niat berkunjung wisatawan, serta daya tarik wisata yang juga berpengaruh signifikan terhadap niat berkunjung wisatawan. 


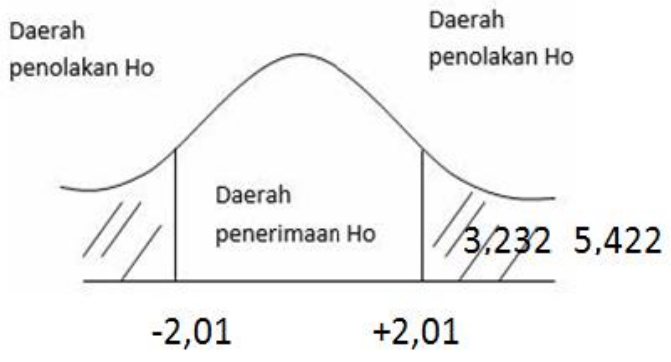

Gambar 3. Kurva Uji t

d. Uji Analisis Regresi Berganda Tabel 4. Tabel Coefficients

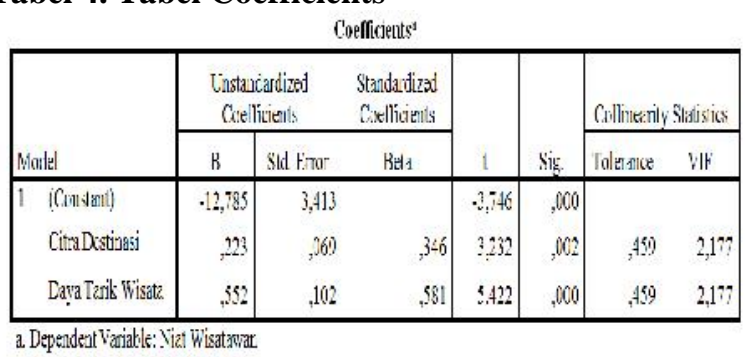

Berdasarkan tabel 4, persamaan model regresi yang terbentuk adalah sebagai berikut:

$\mathrm{Y}=-12,785+0,223 \mathrm{X} 1+0,552 \mathrm{X} 2$

Nilai konstanta sebesar $-12,785$ menunjukkan bahwa niat berkunjung wisatawan adalah sebesar -14,529 dengan anggapan jika tidak ada pengaruh variabel citra destinasi (X1), daya tarik wisata (X2).

Nilai koefisien regresi 0,223 menunjukkan bahwa setiap kenaikan $1 \%$ citra destinasi, maka niat berkunjung wisatawan akan naik sebesar $22,3 \%$ dengan asumsi variabel bebas yang lain tetap atau konstan.

Nilai koefisien regresi 0,552 menunjukkan bahwa setiap kenaikan $1 \%$ daya tarik wisata, maka niat berkunjung wisatawan akan naik sebesar $55,2 \%$ dengan asumsi variabel bebas yang lain tetap atau konstan.

\section{SIMPULAN DAN SARAN}

Berdasarkan uji regresi berganda yang dilakukan, dapat ditarik kesimpulan bahwa kedua variabel bebas yaitu citra destinasi dan daya tarik wisatawan mempengaruhi niatan para wisatawan yang tergolong dalam generasi muda untuk mengunjungi Kampung Wisata Tridi. Dari kedua variabel bebas yang digunakan dalam penelitian ini, variabel daya tarik wisata merupakan variabel yang memiliki pengaruh signifikan lebih besar dibandingkan citra destinasi, sehingga harapannya kedepan, baik pemerintah maupun masyarakat lokal yang mengelola Kampung Wisata Tridi, harus lebih memerhatikan keunikan dari daya tarik dari kampung wisata tersebut. Daya tarik yang dijelaskan dalam penelitian ini termasuk konsep yang ditawarkan, harga dari tiket masuk, dan kemudahan akses menuju lokasi Kampung Wisata Tridi.

Saran dari peneliti mengenai daya tarik dalam hal konsep adalah pembuatan gambar tiga dimensi yang memiliki tema tertentu yang berubah setiap 3 bulan sekali, sebagai contoh dalam satu periode, ditentukan tema mengenai anime Jepang yang sedang disukai para generasi muda, maka semua gambar tiga dimensi pada Kampung Wisata Tridi harus bertema anime Jepang. Sehingga, setiap wisatawan yang berkunjung ulang ke destinasi tersebut dapat memiliki foto yang berbeda beda setiap 3 bulannya.

\section{DAFTAR PUSTAKA}

1. Ali, Hasan. (2011). Marketing Edisi Baru. Yogyakarta. Media Pressindo.

2. Basiya, R dan Hazan Abdul Rozak. 2012. Kualitas Daya Tarik Wisata, Kepuasan dan Niat Kunjungan Kembali Wisatawan Mancanegara di Jawa Tengah. Jurnal Dinamika Kepariwisataan Vol.11 No.2, Oktober 2012. www.unisbank.ac.id/ojs/indeks.php/pdk1/article/dow nload/1715/629. Di Akses 5 Juli 2015. Hal.1-12.

3. Bramwell, W. (2006). Promoting Literacy and Social-emotional Learning through Dialogic Reading. International Reading Association, hlm. 554-564.

4. Crompton, J. L. (1979). An assessment of the image of Mexico as a vacation destination and the influence of geographical location upon that image. Journal of Travel Research, 17 18-23.

5. Chen, Ching-Fu, and Dung Chun Tsai (2007). "How Destination Image and Evaluative Factors affect Behavioral Intentions?" Tourism Management, 28 (4): 1115-1122.

6. Chi, Christina Geng-Qing, and Hailin Qu (2008). "Examining the Structural Relationships of Destination Image, Tourist Satisfaction and Destination Loyalty: An Integrated Approach." Tourism Management, 29(4): 624-636.

7. Dewi, Novrisa, S. 2013. Pengaruh Citra Destinasi Pariwisata Kabupaten Belitung terhadap Perilaku Pasca Berkunjung. Dapat diakses pada: perpustakaan.upi.edu. Universitas Pendidikan Indonesia.

8. Echtner, C. M. and J. R. B. Ritchie. (1991). The Meaning and Measurement of Destination Image. Journal of Tourism Studies.

9. Gravetter, F. J., \& Forzano, L.-A. B. (2009). Research methods for the behavioral sciences. Belmont, CA: Wadsworth Cenage Learning.

10. Handawan, galih, y. (2015). Pengaruh citra destinasi pariwisata waduk sermo terhadap minat wisatawan berkunjung ulang studi kasus pada wisatawan yang pernah berkunjung di waduk sermo, kulon progo. Yogyakarta, Universitas Sanata Dharma Yogyakarta. Skripsi.

11. Ismail, Zurida., dan Ali M, 2004, Assessing student Teachers Understanding of The Biology Syllabus Through Concept Mapping, Proceesding Of The First Int. Conference On Concept Mapping. A.J., Canas, J.D., Novak, F.M., Gonzalez, Eds, Pamplona, Spain.

12. Jorgansen, Louise Gylling. 2004. "An Analysis of a Destination's Image and the Language of 
Tourism" UNIQUELY SINGAPORE , 9 (September), p.13.

13. Page, S. J., Steele, W., dan Connell, J. (2006). Analysing the promotion of adventure tourism: A case study of scotland. Journal of Sport \& Tourism, 11 (1), 51-76

14. Pendit, Nyoman S., 1999, Ilmu Pariwisata Sebuah Pengantar Perdana. Jakarta: Pradnya Paramita.

15. Qu, Hailin, Lisa Hyunjung Kim, and Holly Hyunjung Im (2011). "A Model of Destination Branding: Integrating the Concepts of the Branding and Destination Image." Tourism Management, 32 (3): 465-476.

16. Ratz, T. Puczko, L. (1998). Rural Tourism and Sustainable Development in Hungary. In: Hall, D. International Conference, Conference Proceedings. SAC, Auchincruive, Ayr, pp. 450464.

17. Wang, Chun-yang, and Maxwell K. Hsu (2010). "The relationships of destination image, satisfaction, and behavioral intentions: An integrated model." Journal of Travel \& Tourism Marketing 27 (8): 829-843.

18. Wiendu. 1993. Desa Wisata Dan Lingkungannya. Jakarta: Gramedia.

Sumber internet:

www.BPS.go.id (diakses pada 15 Juni 2017)

www.tripadvisor.co.id (diakses pada 22 Juni 2017) 